\title{
P73冠動脈病変の労働関連危険因子
}

\author{
$\bigcirc$ 服部 真（石川勤医協城北病院）、舟越光彦（九州社医研）、 \\ 長谷川吉則 (千葉健生病院)、佐藤修二（北海道勤医協札幌病院）
}

\section{1.はじめに :}

虚血性心疾患は、代表的な作業関連疾患の一つ と言われている。本学会でも、循環器疾患の作業 関連要因検討委員会が、循環器疾患の発症や悪化 に、物理化学的要因の他、長時間労㗢、夜勤・交 代制勤務や労働人快が関与しているとする豊富な 文献や事例調査を報告している。

しかし、臨床や健康管理の場面で、依然として、 高血圧、高脂血症、糖尿病、喫煙という古典的な 危険因子のみが強調される傾向がある。

そこで、現役労働者の虚血性心疾患にどの要因 がどの程度関与しているのか調べるために、冠動 脈造影検査 $(\mathrm{CAG})$ を受けた現役労働者の診断結果 と危険因子の関連を多変量解析を用いて検討した。

2. 研究方法 :

全国 18 力所の病院で、1998 年に初回のCAG を受 けた 69 歳以下の現役労㗢者 80 人を対象に、CAG 結果と労働関連要因を含む危険因子を調査した。

CAG 結果 冠攣縮 (VS)、正常冠動脈 (NC) に分類し、検查值が 基準值を超えるか治療中の者を危険因子ありとし た。労㗢関連要因は、自己記入式調査票に依った。

3 . 研究結果 :

冠動脈病変別に、古典的危険因子や労働関連危 険因子を比較した。

平均年齢は AMI 群とVS 群が低かった。高血圧 はVS 群が有意に少なく、高脂血症や糖尿病もVS 群が少ない傾向であった。喫煙本数やヌーヒーを早に
3 杯以上飲む習慣は、NC 群が有意に少なく、SS、 VS、AMI 群が多かった。残業を含む週の労働時間、 化事の量が多い、時間や/怜に追われるはVS 群が 有意に多かった。接待が多いはVS 群が有意に多く、 SS 群が有意に少なかった (表 1 )。

喫煙やコーヒーと労働要因との関連も認められた。

何れかの冠病変有り（SS+VS+AMI）を説明する ロ ジスティック回帰モデル（寄与率 0.31）は、喫煙 本数 $(p=0.01)$ 、週労衝時間 $(p=0.02)$ 、高脂血症

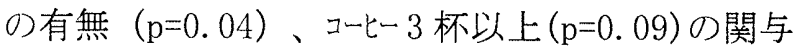
太゙強く、冠攣縮（VS+AMI）を説明するロジスティ ック回帰モデル(寄与率 0.30 ) は、ルルマに追われる $(p=0.02)$ 、喫煙本数 $(p=0.02)$ 、高脂血症の有無 $(\mathrm{p}=0.02)$ 、週労働時間 $(\mathrm{p}=0.03)$ の関与が強かった。

\section{4. 考察、結論 :}

$\mathrm{NC}$ 群の危険因子が多い理由は、危険因子保有が 绿い者程、症状が軽くても $\mathrm{CAG}$ 検査を受けやすい ためと思われる。

本研究は、上記の点を考慮しても、69歳以下の 現役労衝者の冠動脈病変に関しては、年齢、高血 压、高脂血症、糖尿病などの古典的危険因子より も、長時間労㗢、業務過多、汉や時間に追われる、 接待が多いという労㗢関連要因と労㗢要因に関連 した喫煙習慣やューヒー多飲という生活習慣の関与が 大きいことを示唆した。

職場の健康管理には、検査結果以上に、労働時 間、接待や労働外久等の労衝関連要因や生活習慣 に注目することが重要である。

表 1 冠動脈病変と危険因子

\begin{tabular}{|c|c|c|c|c|}
\hline & C $\quad(n=20)$ & SS $\quad(n=17)$ & VS $\quad(n=16)$ & AMI $\quad(n=27)$ \\
\hline 年 齢 \pm SEM** & $57.8 \pm 2.0$ & $54.9 \pm 2.2$ & $46.1 \pm 2.2 \#$ & $48.7 \pm 1.7$ \\
\hline 高血圧 $*$ & $50 \%$ & $47 \%$ & $6 \% \#$ & $37 \%$ \\
\hline 高脂血症 & $29 \%$ & $19 \%$ & $16 \%$ & $35 \%$ \\
\hline 糖尿病 & $25 \%$ & $29 \%$ & $14 \%$ & $32 \%$ \\
\hline 喫煙本数 $\pm \mathrm{SEM} * *$ & $9.3 \pm 4.2 \#$ & $21.4 \pm 4.7$ & $23.8 \pm 5.2$ & $30.6 \pm 4.5$ \\
\hline コーヒ一 3 杯 以上 $*$ & $9 \% \#$ & $30 \%$ & $22 \%$ & $39 \%$ \\
\hline 週労働時間 $\pm \mathrm{SEM} * *$ & $45.7 \pm 2.7$ & $4 \mathrm{~S}^{2} .1 \pm 2.9$ & $55.8 \pm 3.0 \#$ & $57.4 \pm 2.3 \#$ \\
\hline 仕事の量が多い* & $45 \%$ & $40 \%$ & $92 \% \#$ & $61 \% \#$ \\
\hline ルルマに追われる* & $40 \%$ & $27 \%$ & $77 \% \#$ & $59 \%$ \\
\hline 時間に追われる** & $45 \%$ & $40 \%$ & $92 \% \#$ & $65 \%$ \\
\hline 接待が多い** & $20 \%$ & $0 \% \#$ & $61 \% \#$ & $12 \%$ \\
\hline
\end{tabular}

分散分析、Chi二乗検定、Kruskal-Wal1 is 検定（*:p<0.05、**:p<0.01）、

各セルのChi二乗検定 (\#: $\mathrm{p}<0.05)$ 